\title{
Socio-Economic Factors Affecting Rice Production among Smallholder Farmers in Lukulu District, Western Zambia
}

\author{
Emmanuel C. Musaba ${ }^{1^{*}}$, Mundia Mukwalikuli ${ }^{2}$ \\ ${ }^{I}$ Department of Agriculture, School of Agriculture and Natural Resources, Mulungushi University, P.O BOX \\ 80415, Kabwe Zambia. \\ ${ }^{2}$ Kwame Nkrumah University, School of Business, P.O BOX 80404, Kabwe
}

*Corresponding Author: Emmanuel C. Musaba, Department of Agriculture, School of Agriculture and Natural Resources, Mulungushi University, P.O BOX 80415, Kabwe Zambia.

\begin{abstract}
Despite the various efforts to increase rice production in Zambia, productivity has stagnated and rice production has not grown enough to meet domestic demand. This paper analyses socio-economic factors affecting rice production among smallholder farmers in Zambia. Purposive and random sampling techniques were used in sampling the 120 respondents from Lukulu district in Western province of Zambia. Data were analyzed using descriptive statistics and econometric analysis. A Cobb-Douglas regression model was used to estimate the effects of socio-economic factors on smallholder farmers' rice output. It was found that land size, seed quantity, agrochemicals, labor, gender, extension access, and line planting were significant and positively related to rice output while off-farm income had a negative effect. The results suggest that farmers could improve rice output if assisted in accessing inputs (land, seed, herbicides, and labor), extension services and encouraged to adopt improved rice planting farming practices. Since male farmers obtained higher rice output than women farmers, differential effects of gender on rice production in the study area should be considered.
\end{abstract}

Keywords: productivity, rice production, regression, socio-economic analysis

\section{INTRODUCTION}

Rice is an emerging staple food in Zambia which was declared a strategic food crop by the Zambian Government in 2007. The per capita consumption increased from $1.4 \mathrm{~kg}$ per person in 2002 to $4.11 \mathrm{~kg}$ per person in 2014. The total domestic consumption increased from 15,926 metric tonnes (MT) in 2002 to 59,728 MT in 2014. The increase in rice demand was driven by increases in urban population, rising incomes and change in tastes. Although Zambia has vast land and other resources suitable to produce enough rice for her population, domestic rice output has been below domestic demand which has led to importation of rice to satisfy domestic demand. In 2016, the rice deficit was estimated at 35,000 MT (Ministry of Finance and National Planning (MFND), 2017).

Rice is grown in all the 10 provinces of Zambia but the major production areas are: Western province with $46 \%$ of the planted area, followed by Northern (32\%), Muchinga (13\%), Eastern (4\%) and Luapula (4\%) provinces. Rice production is carried out by small-scale farmers under rain-fed conditions and the main production ecologies are the flood plains of big rivers and dambos (MAL and CSO, 2016). Between 2002 and 2015, rice output increased from 11,645 MT to 49,000 MT, this was due to expansion in rice planted area from 12,926 Ha to 40,974 Ha. However, the increase in rice output and rice planted area, was not accompanied by productivity improvement. In fact, national annual average rice yield stagnated at 1.4 MT per Ha for most of the period and from 2010 it decreased to 1.14 MT per Ha (MAL and CSO, 2016). In short smallholder rice growers face persistent low rice productivity, which is below the potential yield of 3 MT per Ha. The low productivity has hindered Zambia's effort to achieve self-sufficiency in rice. The reasons for low productivity included using traditional methods of production with low mechanization, broadcasting of seed, the use of lowyielding tradition varieties, limited fertilizer application, limited weeding of fields, poor water management, limited access to credits, limited access to extension services, and limited access to markets due to poor state of feeder roads (MAL and CSO, 2016).

Given the crucial role of rice in national food security, improvement of rice production and productivity is an overriding need to meet the government objective of national food security or 
selfsufficiency in rice. The country has taken a number of measures to stimulate production in particular in 2011 it launched the National Rice Development Strategy (NRDS) 2011-2015, which aimed at making the country self-sufficient in rice by doubling rice production within 5 years (20112015 ), and increasing production and productivity of locally grown rice by $25 \%$ and $75 \%$, respectively by 2015 .

Recognition of socio-economic differences among farmers, inputs used, and farming methods and their effects on rice production is important for any transformation of the Zambian rice sector. It is against this background that this study attempted to assess the socio-economic factors affecting rice production among small-scale farmers in Western Province the major rice producing area of Zambia.

Understanding of the influence of some socio-economic factors is necessary for designing measures for improving productivity of rice farmers in this area. There is dearth of empirical literature on the influence of socio-economic factors on rice production in Zambia. Hence, this study examines the factors affecting rice farmers' output in Western province largest rice-producing provinces in the country.

\section{EMPIRICAL REVIEW OF DETERMINANTS OF RICE OUTPUT}

Various studies have examined the influence of socio-economic factors on crop output and productivity. Empirical studies on rice have pointed that like the basic inputs namely: seed, fertilizers, pesticides, irrigation and appropriate management, socio-economic factors have significant influence on rice production at farmer's level and also on productivity. A study by Osanyinlusi et al. (2016) examined the determinants of rice farmers' productivity in Ekiti State of Nigeria and found that farm size, level of education and quantity of fertilizer were positively and significantly related to productivity, while years of farming experience and quantity of seeds used were negatively related. Anoja and Unaeze (2008) using a multiple linear regression model found that years of education and land size significantly influence farmers' rice output in Enugu state in Nigeria. Julius and Chukwumah (2014) examined the effects of socio-economic factors on small-scale rice farmers' output in Abuja State, Nigeria using a semi-log function and found that fertilizer application, cost of chemicals, farm size and quantity of seed were significant factors influencing rice output.

In Ebonyi State of Nigeria, Nwaobiala and Adesope (2013) used a Cobb-Douglas regression model to assess determinants of smallholder rice production systems. The results showed that the positive determinants of output of upland rice were age, faming experience, farm size, variable inputs and capital was negative. In the case of swamp rice, the Cobb-Douglas regression estimates showed that coefficients of education, labor cost, farm size, variable inputs and farm income were positively signed and capital was negative.

Mbam and Edeh (2011) assessed the determinants of farm productivity among small-holder rice farmers in Anambra State in Nigeria. They used log-linear functional form and found that farm size, cost of labour and frequency of extension visit were negatively related to farmers productivity levels and the positively signed factors were years of education, fertilizer and use of improved variety.

The reviewed literature confirmed that socio-economic factors influence the productivity of crop farming including rice. The effects of these factors tend to the region specific and as such the influence played by these factors on Zambian small-scale rice farmer need to be analyzed.

\section{MeThodology}

\subsection{Study Area and Data Collection}

The study was carried out in Lukulu district in the Western Province of Zambia. It is situated in the northern part of the province. The district is mostly on the plain, the eastern part sits on Sioma plain and the western part is covered by the Zambezi floodplain. The district falls under agro-ecological region IIb, receives medium rainfall ranging from $800 \mathrm{~mm}$ to $1,000 \mathrm{~mm}$ per annual and temperature of $20 \mathrm{o}$ to $28 \mathrm{o}$ Celcius. It gets flooded in the rain season, and has good potential for rice production. Farmers grow maize, sorghum, and rice and keep pigs and cattle.

Purposive sampling and simple random sampling techniques were used in selecting respondents. First the district was purposively selected out of the 16 districts in Western Province based on high concentration of rice farming. Secondly, six (6) agricultural camps were purposively selectedin district. Finally, 20 farmers were randomly selected per agricultural camp and interviewed using a 
Socio-Economic Factors Affecting Rice Production among Smallholder Farmers in Lukulu District, Western Zambia

structured questionnaire. The information collected included socio-economic aspects, farm characteristics; rice production inputs viz. farm size, labor, agrochemicals, fertilizer and rice output. The data was collected during collected during February and March 2017. A total sample 120 smallholder rice farmers were interviewed for this study and 81 useable questionnaires were used in this analysis.

\subsection{Data Analysis}

Descriptive and inferential statistics were used to analyze the data. These included mean, standard deviation and frequencies; whilst the inferential statistics included regression analysis to determine the factors affecting rice output among small-scale farmers.

\subsection{Analytical Model}

The analytical framework used in the study was based on the production function. The regression analysis was used to determine the relationship between rice farmers' socioeconomics characteristics and rice production. A Cobb-Douglas production function was used to determine the factors that influence rice production among small-scale farmers. The regression model was specified as:

$\mathrm{Y}=\beta_{0} X_{1}^{\beta 1} X_{2}^{\beta 2} X_{3}^{\beta 3} X_{4}^{\beta 4} X_{5}^{\beta 5} X_{6}^{\beta 6} X_{7}^{\beta 7} X_{8}^{\beta 8} \ldots X_{12}^{\beta 12} e^{U}$

Equation 1 was then linearized by taking the natural logarithm, which then yielded the following model:

Ln $Y=\beta_{0}+\beta_{1} \ln X_{1}+\beta_{2} \ln X_{2}+\beta_{3} \ln X_{3}+\beta_{4} \ln X_{4}+\beta_{5} \ln X_{5}+\ldots+\beta_{12} \ln X_{12}+u$

Where;

$\mathrm{Y}=$ total rice output $(\mathrm{kg}) ; \mathrm{X}_{1}=\operatorname{Seed}(\mathrm{kg}) ; \mathrm{X}_{2}=$ land size $(\mathrm{Ha}) \mathrm{X}_{3}=$ Fertilizer $(\mathrm{kg}) ; \mathrm{X}_{4}=$ Agrochemicals (lts); $\mathrm{X}_{5}=$ labour (man days); $\mathrm{X}_{6}=$ Gender of rice farmers; $\mathrm{X}_{7}=$ Extension (visits); $\mathrm{X}_{8}$ $=$ Experience rice farming (years); $X_{9}=$ Distance $(\mathrm{km}) ; X_{10}=$ Off-farm income dummy; $X_{11}=$ Line planting dummy; $X_{12}=$ Improved seed used (dummy); $\beta_{0}=$ constant term; $\beta_{\mathrm{i}}$, = coefficients of the regression model; $\mathrm{Ln}=$ natural logarithm, and $\mathrm{U}=$ error term variable.

All the other variables included in the model were expected to positively affect farmers' rice output. The exceptions were gender and off-farm income which were assumed to be ambiguous and distance which was expected to negatively affect farmers' rice output.

\section{RESUltS AND DISCUSSION}

\subsection{Socio-Economic Characteristics of Respondents}

Table 1 presents the descriptive statistics of selected socio-economic characteristics of small-scale rice farmers in this study. The average age of the rice farmers was 43.3 years. Half of the respondents (49.4\%) were between the age of 20 to 40 years and these were at most productive stage of their life. Another half of the respondents $(50.6 \%)$ were above 40 years old. This suggests that rice farming in the study area has attracted both young and old generations.

It was also revealed that $51 \%$ of the respondents were male and $49 \%$ were female, implying that both sexes were equally involved in rice farming in the study area. Majority of the rice farmers were married (58\%) and the rest were not. The average size of the household was 6.5 persons. This indicates that most households were endowed with enough hands (or family labor) to assist with farming operations and off-farm income activities. About $45.7 \%$ of the rice farmers were engaged in off-farm income generating activities.

Table1. Distribution of respondents according to socio-economic characteristics

\begin{tabular}{|c|c|c|c|c|}
\hline Variable & Category & Frequency & Percent & Mean \\
\hline Gender & Female & 40 & 49.4 & \\
\hline & Male & 41 & 50.6 & \\
\hline Married & No & 34 & 42 & \\
\hline Age group & $20-30$ & 47 & 24.7 & 43.3 years \\
\hline & $31-40$ & 20 & 24.7 & \\
\hline & $41-50$ & 16 & 19.8 & \\
\hline & $51-60$ & 12 & 14.8 & \\
\hline & $>60$ & 13 & 16 & \\
\hline
\end{tabular}


Socio-Economic Factors Affecting Rice Production among Smallholder Farmers in Lukulu District, Western Zambia

\begin{tabular}{|c|c|c|c|c|}
\hline \multirow[t]{4}{*}{ Education } & None & 6 & 7.4 & \\
\hline & Primary & 18 & 22.2 & \\
\hline & Basic & 31 & 38.3 & \\
\hline & Secondary & 26 & 32.1 & \\
\hline \multirow[t]{2}{*}{ Off-farm income } & No & 44 & 54.3 & \\
\hline & Yes & 37 & 45.7 & \\
\hline \multirow[t]{2}{*}{ Owned land } & No & 22 & 27.2 & \\
\hline & Yes & 59 & 72.8 & \\
\hline \multirow[t]{2}{*}{ Hand hoe method } & No & 58 & 71.6 & \\
\hline & Yes & 23 & 28.4 & \\
\hline \multirow[t]{2}{*}{$\begin{array}{c}\text { Improved seed } \\
\text { used }\end{array}$} & No & 60 & 74.1 & \\
\hline & Yes & 21 & 25.9 & \\
\hline \multirow[t]{2}{*}{ Line planting used } & No & 53 & 65.4 & \\
\hline & Yes & 28 & 34.6 & \\
\hline \multirow[t]{3}{*}{ Rice Area (Ha) } & $0.25-0.50$ & 12 & 14.8 & 1.17 ha \\
\hline & 1 & 45 & 55.6 & \\
\hline & $1-2$ & 24 & 29.6 & \\
\hline \multirow[t]{3}{*}{ Rice Prod (kg) } & Below 1500 & 33 & 40.7 & $1983.3 \mathrm{~kg}$ \\
\hline & $1501-2000$ & 27 & 33.3 & \\
\hline & Above 2000 & 21 & 25.9 & \\
\hline
\end{tabular}

The frequency distribution of education showed that $22.2 \%$ had primary education, $38.3 \%$ basic education (grade 7 to 9), 32.1\% had secondary education, and $7.5 \%$ had no formal education. This indicates that most rice farmers in the study area have low levels of education (below secondary) and that may hinder their understanding and application of improved rice farming technologies.

The respondents in the study area had an average of 7 years of experience in rice farming. Majority of rice farmers had traditional land ownership (72.8\%) and the rest $(27.8 \%)$ used rented or borrowed land from other farmers. Crops grown in addition to rice included maize, sorghum and millet.

Adoption of improved rice farming technologies is important for increasing productivity of smallholder agriculture. Improved rice technologies practiced by the rice farmers in the study area included: row or line planting, fertilizer application, herbicide application and using improved rice seed varieties. About $25 \%$ of respondent planted improved rice varieties, and the rest used recycled seed $(75 \%)$. Most farmers used recycled seed because it was readily available and cheaper than improved seed. About a third (34\%) of respondents planted rice in rows or lines instead of broadcasting. For cultivation, some farmers were using hoe-technology $(28.4 \%)$ and others used hired oxen since majority of respondent $(70 \%)$ did not own any cattle. The area planted to rice ranged between 0.5 and 2 hectares, with an average rice planted area of $1.17 \mathrm{ha}$, and average rice produced was $1983.3 \mathrm{~kg}$ per farm during 2016.

Quantity of rice produced was between 7000 and $4500 \mathrm{~kg}$, with an average of $1983.3 \mathrm{~kg}$ per farm. The average farm size was $3.69 \mathrm{Ha}$, out of which $1.17 \mathrm{Ha}$ was planted to rice. In terms of average yield per hectare, the farmers in the study area obtained $1,676 \mathrm{~kg}$ per hectare. This indicates that most farmers faced low rice productivity since their actual yields were below the potential yield of 3 tons per hectare which is attainable from improved rice varieties.

The various production inputs used in rice production included seed, land, agrochemicals (herbicides), fertilizer and labor. The average amounts used were $8.25 \mathrm{~kg}$ of seed, $184.2 \mathrm{~kg}$ of fertilizer, 6.33 liters of agricultural chemicals and 57 man days of labor (see Table 2). Distribution of rice production indicated that, rice output of majority of rice farmers $(40.7 \%$ ) was below $1500 \mathrm{~kg}$, while $33 \%$ of farmers had between $1500-2000 \mathrm{~kg}$ of rice output, and $26 \%$ of farmers produced above $2000 \mathrm{~kg}$ of rice. This showed that majority were low producers with production of less than $2000 \mathrm{~kg}$ of rice.

Table2. Descriptive statistics of selected variables used in the regression

\begin{tabular}{|c|c|c|c|c|c|}
\hline & $\mathrm{N}$ & Minimum & Maximum & Mean & Std. Deviation \\
\hline Extension & 81 & .00 & 11.00 & 4.29 & 3.08 \\
\hline Rice Output $(\mathrm{kg})$ & 81 & 700.00 & 4500.00 & 1983.33 & 1171.45 \\
\hline Rice area $(\mathrm{Ha})$ & 81 & 0 & 2.00 & 1.17 & 0.51 \\
\hline
\end{tabular}


Socio-Economic Factors Affecting Rice Production among Smallholder Farmers in Lukulu District, Western Zambia

\begin{tabular}{|c|c|c|c|c|c|}
\hline Seed (Kg) & 81 & 4.00 & 10.00 & 8.26 & 1.84 \\
\hline Fertilizer (kg) & 81 & 50.00 & 400.00 & 184.26 & 95.15 \\
\hline Agrochemicals (litres) & 81 & 2.00 & 10.00 & 6.33 & 2.64 \\
\hline Labor (Mandays) & 81 & 15.00 & 120.00 & 57.1852 & 27.23 \\
\hline
\end{tabular}

\subsection{Regression Results of the Estimated Production Function}

The results in Table 4 reveal that $76.9 \%$ of the variation in rice production is explained by the variables in the model. The result indicate that rice production was positively and significantly influenced by land size $(p<0.01)$, seed quantity used $(p<0.05)$, agrochemical application $(p<0.01)$, labour $(\mathrm{p}<0.05)$, gender $(\mathrm{p}<0.01)$, extension contact $(\mathrm{p}<0.10)$ and line planting $(\mathrm{p}<0.01)$.

Table4. Multiple regression analysis showing influence of selected socio-economic factors onrice production.

\begin{tabular}{|c|c|c|c|c|}
\hline Variables & Coefficients & Std. Error & t & Sig. \\
\hline (Constant) & $1.289^{* *}$ & 0.587 & 2.196 & 0.032 \\
\hline LNSeed & $0.488^{* *}$ & 0.188 & 2.600 & 0.012 \\
\hline LNLandsqm & $0.425^{* * *}$ & 0.131 & 3.232 & 0.002 \\
\hline LNFertilizer & 0.136 & 0.102 & 1.328 & 0.189 \\
\hline LNAgrochemicals & $0.306^{* * *}$ & 0.071 & 4.298 & 0.000 \\
\hline LNMandays or Labor & $0.162^{* *}$ & 0.071 & 2.298 & 0.025 \\
\hline Gender & $0.199^{* * *}$ & 0.069 & 2.870 & 0.006 \\
\hline LnExtension & $0.097 *$ & 0.052 & 1.844 & 0.070 \\
\hline LnExperience & 0.149 & 0.120 & 1.234 & 0.222 \\
\hline LnDistance & -0.061 & 0.057 & -1.076 & 0.286 \\
\hline Off-farmincome & $-0.163 * *$ & 0.068 & -2.404 & 0.019 \\
\hline Line planting USED & $0.280^{* * *}$ & 0.071 & 3.936 & 0.504 \\
\hline Improved Seed USED & -0.054 & 0.080 & -0.672 & \\
\hline
\end{tabular}

The coefficients of seed (0.488) and agrochemicals (herbicides) (0.306) were positively signed and significant at $5 \%$ and $1 \%$ level of probability, respectively. The result is consistent with a priori expectation and agrees with the findings of Onyenweaku et al., (2010) and Basorun et al. (2012) that there was a positive relationship between agrochemicals and quantity of rice seeds used in rice production in Nigeria.

The coefficient of land size (0.425) was positive and highly significant at $1 \%$ level of probability. This implies that an increase in rice land size will result to an increase in the output of rice in the study area. This is in agreement with a priori expectation. This result is in conformity with the findings of Ezeh (2006), Anoja et al. (2008) and Nwaobiala (2013) who found that farm size has positive influence on the output of rice in Nigeria.

The coefficient of labor (0.162) was positive and significant at 5.0\% level of probability. This implies that an increase in the number of man-days of labor will lead to an increase in rice output in the study area. This agrees with a priori expectation and conforms to the findings of Nwaobiala, (2013) who found a positive relationship between cost of labour used by IFAD farmers and their farm output in Abia and Cross River States, Nigeria.

As expected contact with extension workers had a positive significant $(\mathrm{p}<0.10)$ relationship with rice output. This suggests that farmers experience higher rice output as more contacts are made with extension agents in the study area. This supports the findings Osanyinlusi et al (2016) which reported that extension services enhanced farmers' productivity in Nigeria. It also concurs with the findings of Hoque and Haque (2014) that information source (extension) positively influenced profitability of rice seed production in Bangladesh.

Off-farm income had a negative and significant $(\mathrm{p}<0.05)$ influence on rice output. This implies that any increase in farmer participation in off-farm income-generating activities, reduces time for rice cultivation and leads to a decrease in rice production. Thus off-farm income participation is a significant determinant of rice output in the study area.

The coefficient of line planting (0.280) was positive and significant at $1 \%$ probability level. This result agrees with apriori expectation. This implies that improving the method of planting from broadcasting to line or row planting would increase rice output in the study area. 
Socio-Economic Factors Affecting Rice Production among Smallholder Farmers in Lukulu District, Western Zambia

\section{CONCLUSION}

Rice production is an important source of livelihood for some small-scale farmers in Western province of Zambia. The study examined and determined the socio- economic factors that influenced rice production using data from Lukulu district. The Cobb-Douglas regression model showed that land size, seed quantity, agrochemicals, labor, gender, extension, lines planting were significant and positively related to rice output while off-farm income had a negative effect. These results suggest that an increase in land size, seed, agrochemical and labor use would improve rice production by $0.424 \%, 0.487 \%, 0.305 \%$ and $0.162 \%$, respectively. While a unit increase in gender, extension visit and line planting would increase rice output by $0.198 \%, 0.096 \%$ and $0.280 \%$, respectively. In addition, the negative sign of the off-farm income coefficient implies that engaging in off-farm income generating activities causes rice production to decrease. The other variables namely fertilizer, experience, distance and seed type had no significant influence on rice production in the study area. The implications of the findings were that farmers could improve rice output if assisted in accessing production resources namely land, improved seed, herbicides, and labor, as well as extension services and encouraged to practice line planting. Since male farmers obtained higher rice output than women farmers, differential effects of gender on rice production in the study area should be considered.

\section{REFERENCES}

[1] Basorun O.J. and Julius, O.F. 2012. Factors Influencing Rice production in Igbemo-Ekiti region Nigeria. Journal of Agriculture, Food \& Environmental Science 5(1):

[2] Ezeh, C.I. 2006. Socio - economic determinants of output and profit levels of smallholder rice production systems in Abia State, Nigeria. Journal of Research in Agriculture 3(3): 44 - 60.

[3] Government of the Republic of Zambia. 2017. 7th National Development Plan Lusaka Zambia, Ministry of Finance and national planning, Lusaka

[4] Hoque M. Z. and Haque M. E. 2014. Socio-economic Factors Influencing Profitability of Rice Seed Production in Selected Areas of Bangladesh. The Agriculturists 12(1): 33-40 (2014)

[5] Ministry of Agriculture and Livestock (MAL). 2016. The Crop foresting survey for 2015/2016 agricultural season and the food balance sheet status for 2016/2017 marketing season. Lusaka, Zambia.

[6] Ministry of Agriculture and Livestock (MAL) and Central statistics Office (CSO). 2016. The 2015/2016 Crop foresting survey Results Presentation, Lusaka, Zambia.

[7] Mbam, B.N. and Edeh, H.O. 2011. Determinants of farm productivity among smallholder rice farmers in Anambra State, Nigeria. Journal of Animal and Plant Sciences, 2011 Vol. 9 (3): 1187- 1191.

[8] Mustapha, S. B, Undiandeye U.C., A. M. Sanusi, A. M. Bakari S. 2012. Analysis of adoption of improved rice production technologies in Jeer local government area of Borno state, Nigeria; International Journal of Development and Sustainability 1(3): 1112-1120.

[9] Nwaobiala, C.U. 2010. Economic Analysis of Swamp Rice Production in Ebonyi Southern Agricultural Zone of Ebonyi State, Nigeria. Journal of Agriculture and Social Research (JASR) 6 (2): 44-48.

[10] Nwaobiala C.U., Okpara M.,Adesope O.M. 2013. Economic Analysis of Small Holder Rice Production Systems in Ebonyi State South East, Nigeria. Russian Journal of Agricultural and Socio-Economic Sciences, 11(23).

[11] Obasi, P. C., Henri-Ukoha A., Ukewuihe I. S. and Chidiebere-Mark N. M. 2013. Factors Affecting Agricultural Productivity among Arable Crop Farmers in Imo State, Nigeria. American Journal of Experimental Agriculture 3(2):443-454.

[12] Onoja, A. O. and Unaeze, H. C. 2008. Socio-economic determinants of productivity and income of rice farmers in Udenu local government areas, Enugu state, Nigeria. Journal of Agriculture and Social Research vol. 8 (2):125-130.

[13] Onyenweaku, C.E., Okoye, B.C and Okorie, K. C. 2010. Determinants of Fertilizer Adoption by Rice Farmers in Bende Local Government Area of Abia State, Nigeria. Nigerian Agricultural Journal 41 (2):1 - 6.

[14] Osanyinlusi O.I and Adenegan K.O. 2016. The determinants of rice farmers' productivity in EkitiState, Nigeria. Greener Journal of Agricultural Sciences, 6(2):049-058

Citation: Emmanuel C. Musaba, Mundia Mukwalikuli, "Socio-Economic Factors Affecting Rice Production among Smallholder Farmers in Lukulu District, Western Zambia" International Journal of Research Studies in Agricultural Sciences (IJRSAS), 2019; 5(11), pp. 35-40, http://dx.doi.org/10.20431/2454-6224.0511005

Copyright: () 2019 Authors. This is an open-access article distributed under the terms of the Creative Commons Attribution License, which permits unrestricted use, distribution, and reproduction in any medium, provided the original author and source are credited. 